\title{
Osmotic and heat treatments on control of fungi associated with seeds of Eugenia brasiliensis and E. pyriformis (Myrtaceae) ${ }^{1}$
}

\author{
Cibelle Ferreira Françoso ${ }^{2 *}$, Claudio José Barbedo²
}

\begin{abstract}
Desiccation sensitive seeds, such as those of Eugenia brasiliensis Lam. (grumixama) and E. pyriformis Cambess. (uvaia), also known as recalcitrant, need to be stored with high water content and temperatures above $0^{\circ} \mathrm{C}$. Such conditions keep these seeds with high metabolism, thus reducing their longevity, and allowing the development of microorganisms, especially fungi, accelerating their deterioration speed. Heat and osmotic treatments have shown some success for the control of some fungi associated with these seeds. However, to better measure the effectiveness of these treatments, the evaluation criteria needs to be refined, taking into account not only their incidence but also their intensity. Thus, in the present study, the percentage of seeds infected by the fungi (incidence) as well as the degree of infection on the seed surface (severity) of E. brasiliensis and E. pyriformis were evaluated after applying heat and osmotic treatments which controlled most fungi found in these seeds, except for Fusarium sp. and Penicillium sp. The evaluation of the severity showed that the effect of the treatments is not only quantitative, reducing the number of infected seeds; there was also a change in the development of the fungi, often reducing the severity of the infection, thus enabling the detection of differences between treatments that were not easily recognized when only using the incidence evaluation.
\end{abstract}

Index terms: osmotherapy, thermotherapy, severity.

\section{Tratamentos osmóticos e térmicos no controle de fungos associados a sementes de Eugenia brasiliensis e E. pyriformis (Myrtaceae)}

\begin{abstract}
RESUMO - Sementes intolerantes à desidratação e às baixas temperaturas, como as sementes de Eugenia brasiliensis Lam. (grumixameira) e E. pyriformis Cambess. (uvaieira), denominadas recalcitrantes, precisam ser armazenadas com alto teor de água $\mathrm{e}$ temperaturas acima de $0^{\circ} \mathrm{C}$. Tais condições mantêm as sementes com metabolismo elevado, reduzindo sua longevidade, e propiciam o desenvolvimento de microrganismos, principalmente os fungos, acelerando sua velocidade de deterioração. Resultados recentes apontam algum sucesso dos tratamentos térmicos e osmóticos no controle de alguns fungos associados a essas sementes. Contudo, para melhor aferição da eficácia desses tratamentos há necessidade de refinar os critérios de avaliação, considerando-se não apenas a incidência, mas, também, sua intensidade. Assim, no presente trabalho avaliou-se, além da porcentagem de sementes infectadas pelos fungos (incidência), o grau de infecção na superfície da semente (severidade) de E. brasiliensis e E. pyriformis após a aplicação de tratamentos térmicos e osmóticos. Os tratamentos osmóticos e térmicos controlam a maioria dos fungos presentes em sementes de E. brasiliensis e E. pyriformis, mas apresentam baixa eficiência para o controle da incidência de Fusarium sp. e Penicillium sp. A avaliação da severidade permitiu observar que o efeito dos tratamentos não é apenas quantitativo, reduzindo o número de sementes infectadas, ocorrendo também alteração no desenvolvimento dos fungos, por vezes reduzindo a severidade da infecção, permitindo, assim, detectar diferenças entre tratamentos não identificáveis na avaliação da incidência.
\end{abstract}

Termos para indexação: osmoterapia, termoterapia, severidade.

\section{Introduction}

Seeds of Eugenia brasiliensis Lam. (grumixama) and $E$. pyriformis Cambess. (uvaia), sensitive to dehydration, maintain high metabolism during storage and provide a favorable environment for the development of microorganisms, increasing considerably the speed of deterioration (Delgado and Barbedo, 2012; Parisi et al., 2013; Françoso and Barbedo, 2014). The removal of the main source of inoculum by chemical (fungicides) or physical (heat and osmotic) treatments of seeds can reduce the speed of this deterioration (Oliveira et al., 2011; Françoso and Barbedo, 2014). Tanaka et al. (2003) found a

${ }^{1}$ Submitted on 02/04/2016. Accepted for publication on 07/27/2016.

${ }^{2}$ Instituto de Botânica, Núcleo de Pesquisa em Sementes, 04301-902 - São Paulo, SP, Brasil.

*Corresponding author $<$ cibelle_ff@hotmail.com> 
reduction in the intensity of symptoms of gray mold (Botrytis cinerea), anthracnose (Colletotrichum spp.) and wilt caused by Fusarium oxysporum f. sp. phaseoli and Verticillium dahliae with heat-treat irrigation water. By contrast, by using hydric restriction (-0.6 MPa) in agar (PDA), induced by mannitol and sodium chloride, Machado et al. (2007) found a reduction in the mycelial growth of Fusarium oxysporum f. sp. vasinfectum.

The control of fungal development by seed treatment can also be assessed quantitatively, i.e., by evaluating not only the incidence, but also the severity of fungal development. Moraes et al. (2003), for example, found a high correlation between incidence and severity in the seed health tests in corn seeds subjected to chemical control of Fusarium moniliforme. However, in recalcitrant seeds, seed health analyses are usually only qualitative (incidence), hindering a more detailed efficiency assessment of treatments for control of associated fungi. This is due, in part, to the lack of an appropriate methodology for quantitative evaluation of seed health tests. Thus, it is difficult to refine the fungi control treatments so that they can be recommended for seeds of Eugenia.

In order to obtain a method for refining the evaluation of the treatment effect on fungal development, as well as check the efficiency of heat and osmotic treatments to control fungi associated with seeds of Eugenia pyriformis Cambess. and E. brasiliensis Lam. (Myrtaceae), in the present study we analyzed the incidence (percentage of infected seeds) and severity (degree of infection on the surface of the seed) of fungi in seeds subjected to such treatments.

\section{Material and Methods}

Fruits of Eugenia pyriformis and E. brasiliensis were collected from mother plants planted in the Jardim Botânico de São Paulo (Botanical Garden), São Paulo state, Brazil (2338S and $46^{\circ} 37^{\prime} \mathrm{W}$ ), respectively in October and December 2013. The seeds were extracted manually with the help of a sieve under running water; the seeds damaged by insects and immature seeds were eliminated. Then, they were placed in polyethylene bags and stored in a cold chamber at $7{ }^{\circ} \mathrm{C}$ (Kohama et al., 2006), until experimental setup, not exceeding 15 days.

The experimental design for all experiments, into each species, was completely randomized with a $7 \times 3$ factorial arrangement (treatments $\mathrm{x}$ storage periods) and four replications. Each species has been subjected to two heat treatments $\left(55^{\circ} \mathrm{C}\right.$ for $30 \mathrm{~min}$, called Heat-1; $55^{\circ} \mathrm{C}$ for $150 \mathrm{~min}$, called Heat-2) and two osmotic treatments (-3.4 MPa applied only initially, called Osm-1; -3.4 MPa applied initially and reapplied at 30 days of storage, called Osm-2). Seeds that did not receive heat treatment were called Heat- 0 and those which received no osmotic treatment were called Osm- 0 . The association of both types of treatments was also analyzed. In this way, there were seven levels of treatments: Heat- 0 Osm- 0 (control), Heat-1 Osm-0, Heat-2 Osm-0, Heat-0 Osm-1, Heat-0 Osm-2, Heat-1 Osm-1 and Heat-2 Osm-1. Part of the seeds of each treatment was stored for 30 and 60 days, in polyethylene bags, in a cold chamber at $7{ }^{\circ} \mathrm{C}$ (Kohama et al., 2006).

For the application of the heat treatment, the seeds were immersed in distilled water, in the ratio of 1:5 (seed : water, in mass), in glass Beckers placed in an air circulation oven, at temperatures and periods described above. The Beckers were periodically shaken and, at the end of the period of exposure, the seeds were cooled with distilled water at room temperature for two hours and placed on filter paper to remove excess surface water (Oliveira et al., 2011; Françoso and Barbedo, 2014).

The osmotic treatment consisted of incubation of seeds in a solution of polyethylene glycol 6000 (PEG) for seven days in germination boxes at $7{ }^{\circ} \mathrm{C}$. After the osmotic treatments, the seeds were washed (five consecutive times) in distilled water to remove the residual PEG solution (Oliveira et al., 2011). The osmotic solutions were prepared by adjusting the concentration of PEG as a function of incubation temperature (Michel and Kauffmann, 1973), and water potential was cheked in the analyzer WP4 (Decagon, Pullman, USA).

The association of treatments was performed with the heat treatment first and, after the cooling described earlier, the seeds were incubated in the osmotic treatment, following the same procedure of the treatments alone.

The seeds were initially (after extraction) analyzed for water content and for their physiological quality (germinable seeds and germination) and health (health test), as well as after the application of the heat and osmotic treatments and after storage periods of 30 and 60 days.

Water content was determined gravimetrically in an air circulation oven at $103{ }^{\circ} \mathrm{C}$ for $17 \mathrm{~h}$ (ISTA, 2016), using four replicates of five seeds. The results were expressed in percentage terms, on a wet basis.

The germination test was conducted in Germitest paper rolls, previously moistened (Brasil, 2009), kept in germination chambers regulated for $25 \pm 1{ }^{\circ} \mathrm{C}$, with continuous light and $100 \%$ relative humidity (Delgado and Barbedo, 2007). The evaluations were performed every four days until 70 days (Kohama et al., 2006), recording the percentage of seeds with primary root emission (germinable seeds), normal developed seedlings (germination) and germinable seeds that have not developed seedlings (here referred to as abnormal). For these tests, four replications of 20 and 25 seeds were used respectively for $E$. pyriformis and E. brasiliensis.

The health quality of seeds was assessed analyzing the 
percentage of seeds infected by each fungus (incidence) and the area of the seed covered by the colony (severity).

The seed health test was performed by the Blotter Test (Brasil, 2009). The seeds were evenly distributed in Petri dishes (90x15 mm), containing three sheets of filter paper moistened with distilled water and incubated for seven days at $20 \pm 2{ }^{\circ} \mathrm{C}$ and photoperiod of 12 hours of light/dark, using four replications of 20 seeds for E. pyriformis and 25 seeds for $E$. brasiliensis, with five seeds per plate. The fungi were identified and counted by examining the fungal colonies developed in the seeds with the aid of a stereoscopic microscope. To calculate the incidence of fungi in seeds, in percentage terms, each fungus was analyzed individually. Each analysis considered the number of seeds with the presence of the analyzed fungus compared with the total number of incubated seeds. In some cases, the identification of the fungus was complemented by the visualization of morphological characteristics in an optical microscope (Barnet and Hunter, 1999).

For the calculation of severity, the development of each fungus on the surface of the seeds was analyzed individually, and quantified by a visual scale, adapted from Moraes et al. (2003) and Tanaka et al. (2003), considering the main physiognomic features, as described below: Zero - seed not infected by the analyzed fungus; Traces - growth up to $10 \%$ of the seed, with small colonies, and in a very small number; Low - growth up to $40 \%$ of the seed; Moderate - growth from 41 to $100 \%$ of the seed, with colonies with superficial and slow growth; High - growth from 41 to $100 \%$ of the seed, with a dense and evenly distributed colony. The final evaluation also took into account the percentage of seeds with total absence of fungi (non-infected). The final results were presented in percentage terms.

The assessment of the development of Penicillium sp. and Fusarium sp., through incidence and severity, was used as the main benchmark for the analysis of treatments efficiency in controlling fungal development. This was needed because these fungi were recurrent and persistent in Eugenia spp. seeds which were stored, both in the present work and in previous studies (Oliveira et al., 2011; Françoso and Barbedo, 2014).

The evaluations of physiological quality were based on the comparison of factorial analysis $\left(\mathrm{F}_{\text {test }}, \mathrm{p}<0.05\right)$, without transformation of data, separately for each species. The means for physiological variables were compared by Tukey's test (Santana and Ranal, 2004) and the means of the variables for seed health were measured with their respective standard deviations.

\section{Results and Discussion}

Penicillium sp., Fusarium sp., Pestalotiopsis sp., Phoma sp., Phomopsis sp. and Cladosporium sp. were present in seeds of both species, but Fusarium sp., Colletotrichum sp. and Botrytis sp. occurred only in E. pyriformis. However, with the exception of Penicillium sp. and Fusarium sp., the fungi showed reduction in the incidence after storage or after the treatment (data not shown), often reduced to zero, following the trend observed in previous studies (Françoso and Barbedo, 2014). Fungi of the genus Fusarium and Penicillium have shown a high incidence and persistence in studies with recalcitrant seeded species (Andréo et al., 2006; Oliveira et al., 2011; Françoso and Barbedo, 2014; Parisi et al., 2016); thus, they will be used as a reference in health tests to evaluate the efficiency of treatments in fungal control.

In E. pyriformis, the analysis of the incidence indicates low contamination by Penicillium sp. (Figure 1); however, Fusarium sp. showed high incidence: $100 \%$ in most treatments (Figure 1B); thus, it is not possible to observe the effect of treatments on fungal control.

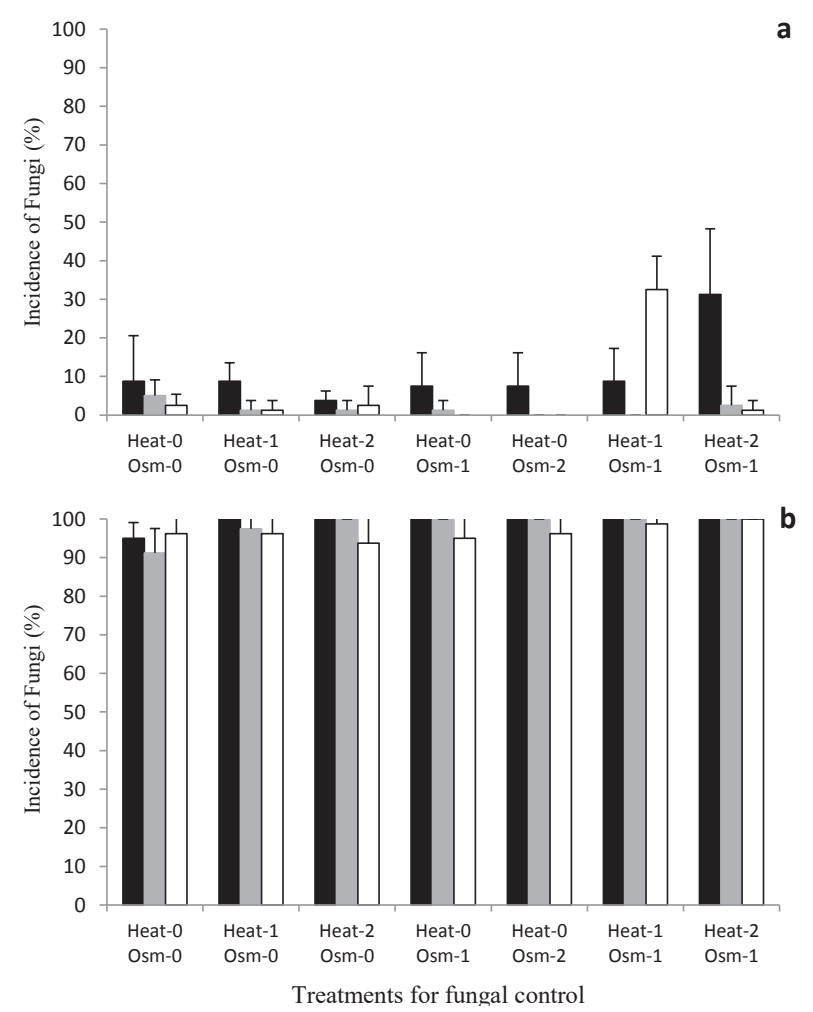

Figure 1. Incidence (\%) of Penicillium sp. (a) and Fusarium sp. (b) in seeds of E. pyriformis subjected to heat treatments (Heat-0: no heat treatment; Heat-1:55 ${ }^{\circ} \mathrm{C} / 30 \mathrm{~min}$; Heat2: $55^{\circ} \mathrm{C} / 150 \mathrm{~min}$ ) and osmotic treatments (Osm- 0 : no osmotic treatment; Osm-1: $-3.4 \mathrm{MPa} / 7$ days; Osm-2: $-3.4 \mathrm{MPa} / 7$ days reapplied at 30 days). Black bars: nonstored seeds; gray bars: after 30 days of storage; white bars: after 60 days of storage. The means and standard deviations are shown. 
Thus, when analyzing only the incidence of the fungi, there was no significant difference between the control and the treated seeds. However, the analysis of severity shows a reduction in the high and moderate development of Fusarium sp., in Heat-1 Osm-0 (Figure 2B), especially throughout storage (Figures $2 \mathrm{D}$ and $\mathrm{F}$ ); at 60 days of storage, the seeds showed a lower rate of high growth. Thus, especially in the long term, the application of the treatment Heat- 1 Osm- 0 reduced the intensity of infestation by Fusarium sp.
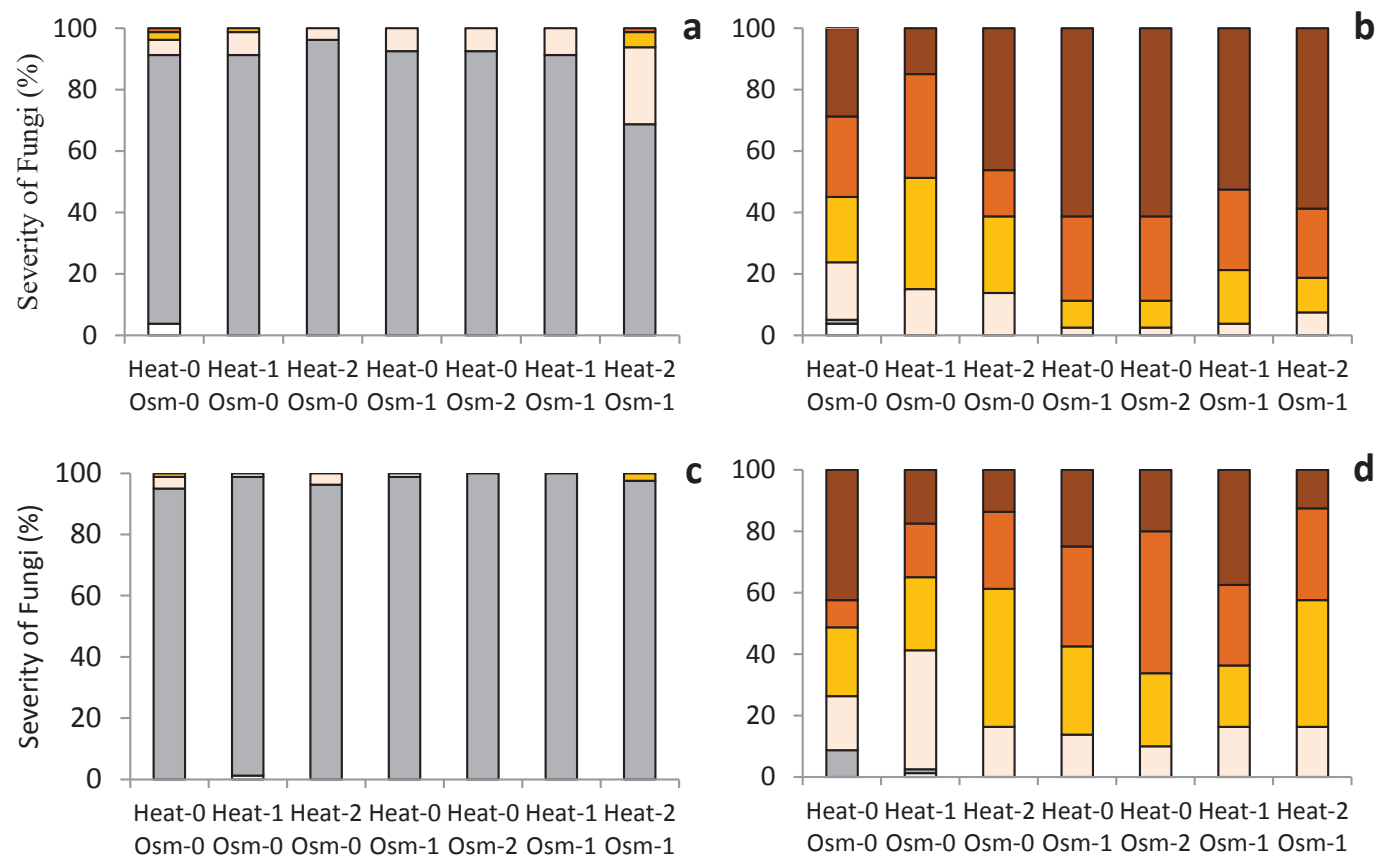

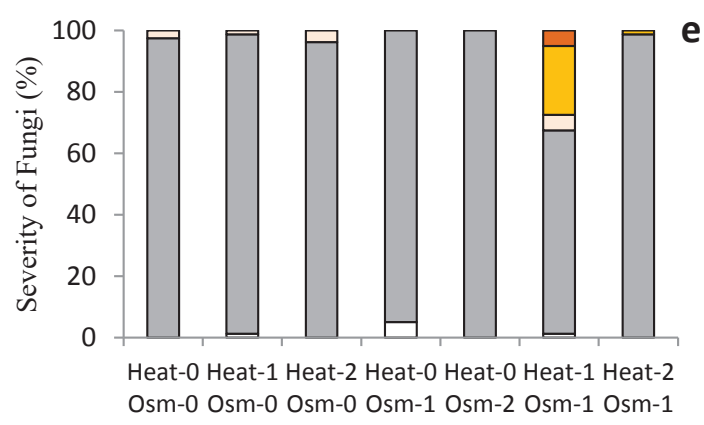

Treatments for fungal control

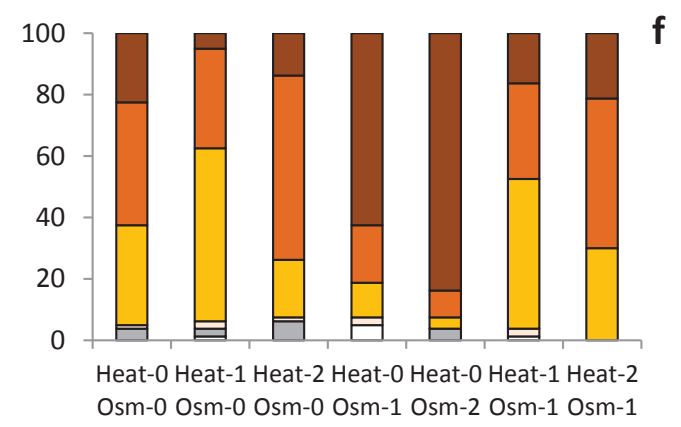

Treatments for fungal control

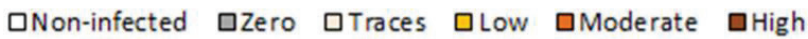

Figure 2. Severity (\%) initially (a and b) and after storage for 30 (c and d) and 60 days (e and f) of Penicillium sp. (a, c and e) and Fusarium sp. (b, d and f) in seeds of E. pyriformis subjected to heat treatments (Heat-0: no heat treatment; Heat-1: $55^{\circ} \mathrm{C} / 30 \mathrm{~min}$; Heat-2: $55^{\circ} \mathrm{C} / 150 \mathrm{~min}$ ) and osmotic treatments (Osm-0: no osmotic treatment; Osm-1: -3.4 MPa/7 days; Osm-2: -3.4 MPa/7 days reapplied at 30 days). Caption: Zero - seed not infected by the analyzed fungus; Traces - small colonies, and in a very small number; Low - weak and sparse growth up to $40 \%$ of the seed; Moderate - moderate growth from 41 to $100 \%$ of the seed, with colonies with superficial and slow growth; High - intense growth from 41 to $100 \%$ of the seed, with dense and evenly distributed colony. Means are show in percentage terms.

With the implementation of the treatments in seeds of E. pyriformis, there was a significant reduction, initially, of germinable seeds and germination. However, in Heat-1 Osm0 , after storage, the values were similar to or higher than those found in Heat-0 Osm-0 (Table 1).

As for E. brasiliensis, Heat-2 Osm-0 was the treatment that best controlled the incidence of Fusarium sp. and unlike Heat-2 Osm-1, the effect was maintained until 60 days of 
storage (Figure $3 \mathrm{~B}$ ). Although there was an increase in the incidence of Penicillium sp. in both treatments (Figure 3), its development was low and in the form of traces, mainly at 60 days of storage in Heat-2 Osm-0 (Figure 4E). In this way, Heat-2 Osm-0 was the treatment that had better health control in the long term in the seeds of E. brasiliensis.

Table 1. Germinable seeds (\%), germination (\%) and abnormal seeds (\%) initially and after 30 and 60 days of storage, of Eugenia pyriformis subjected to heat treatments (Heat-0: no heat treatment; Heat-1: $55{ }^{\circ} \mathrm{C} / 30 \mathrm{~min}$; Heat-2: $55{ }^{\circ} \mathrm{C} / 150 \mathrm{~min}$ ) and osmotic treatments (Osm-0: no osmotic treatment; Osm-1: $-3.4 \mathrm{MPa} / 7$ days; Osm-2: -3.4 $\mathrm{MPa} / 7$ days reapplied at 30 days $)^{(1)}$.

\begin{tabular}{|c|c|c|c|}
\hline \multirow{3}{*}{ Seed treatments } & \multicolumn{3}{|c|}{ Storage } \\
\hline & Initial & 30 days & 60 days \\
\hline & \multicolumn{3}{|c|}{ Germinable Seeds } \\
\hline Heat-0 Osm-0 & $100 \mathrm{aA}$ & 73 bcB & $85 \mathrm{aB}$ \\
\hline Heat-1 Osm-0 & 83 bA & $90 \mathrm{dA}$ & $94 \mathrm{aA}$ \\
\hline Heat-2 Osm-0 & $73 \mathrm{bcB}$ & $81 \mathrm{cdAB}$ & $95 \mathrm{aA}$ \\
\hline Heat-0 Osm-1 & $58 \mathrm{cdA}$ & $51 \mathrm{dA}$ & $44 \mathrm{bA}$ \\
\hline Heat-0 Osm-2 & $58 \mathrm{cdA}$ & $56 \mathrm{cdA}$ & $39 \mathrm{bB}$ \\
\hline Heat-1 Osm-1 & $59 \mathrm{cdB}$ & $75 \mathrm{cdA}$ & $81 \mathrm{aA}$ \\
\hline Heat-2 Osm-1 & $50 \mathrm{~dB}$ & $80 \mathrm{cdA}$ & $91 \mathrm{aA}$ \\
\hline \multirow[t]{2}{*}{$\mathrm{CV}$} & $11.25 \%$ & & \\
\hline & \multicolumn{3}{|c|}{ Germination } \\
\hline Heat-0 Osm-0 & $97 \mathrm{aA}$ & $58 \mathrm{bcB}$ & $64 \mathrm{aB}$ \\
\hline Heat-1 Osm-0 & $69 \mathrm{bA}$ & $75 \mathrm{aA}$ & $69 \mathrm{aA}$ \\
\hline Heat-2 Osm-0 & $24 \mathrm{dC}$ & $40 \mathrm{~dB}$ & $60 \mathrm{aA}$ \\
\hline Heat-0 Osm-1 & $42 \mathrm{cA}$ & $41 \mathrm{dcA}$ & $28 \mathrm{bB}$ \\
\hline Heat-0 Osm-2 & $42 \mathrm{cA}$ & 49 bcdA & $21 \mathrm{bB}$ \\
\hline Heat-1 Osm-1 & $28 \mathrm{cdB}$ & $61 \mathrm{abA}$ & $61 \mathrm{aA}$ \\
\hline Heat-2 Osm-1 & $12 \mathrm{~dB}$ & $55 \mathrm{bcdA}$ & $60 \mathrm{aA}$ \\
\hline \multirow[t]{2}{*}{$\mathrm{CV}$} & $15.96 \%$ & & \\
\hline & \multicolumn{3}{|c|}{ Abnormal } \\
\hline Heat-0 Osm-0 & $3 \mathrm{cB}$ & $15 \mathrm{bAB}$ & $21 \mathrm{abA}$ \\
\hline Heat-1 Osm-0 & $14 \mathrm{aA}$ & $15 \mathrm{bA}$ & $25 \mathrm{abA}$ \\
\hline Heat-2 Osm-0 & $49 \mathrm{bcA}$ & $41 \mathrm{aA}$ & $35 \mathrm{aA}$ \\
\hline Heat-0 Osm-1 & $15 \mathrm{bcA}$ & $10 \mathrm{bA}$ & $16 \mathrm{bA}$ \\
\hline Heat-0 Osm-2 & $15 \mathrm{bcA}$ & $8 \mathrm{bA}$ & $18 \mathrm{abA}$ \\
\hline Heat-1 Osm-1 & $31 \mathrm{abA}$ & $14 \mathrm{bB}$ & $20 \mathrm{abAB}$ \\
\hline Heat-2 Osm-1 & $38 \mathrm{aA}$ & $25 \mathrm{abA}$ & $31 \mathrm{abA}$ \\
\hline $\mathrm{CV}$ & $38.97 \%$ & & \\
\hline
\end{tabular}

${ }^{(1)}$ Means followed by the same letter (lower case: comparison within the columns; capital letters: comparison within the rows) do not differ by Tukey's test at $5 \%$ probability.

Initially, Heat-0 Osm-0 of E. brasiliensis showed $82 \%$ of germinable seeds, but only $31 \%$ of germination (Table 3 ).
Nevertheless, these seeds showed a low incidence and severity of fungi (Figures 3 and 4), indicating that there was no relationship with seed health. With the implementation of Heat-2, alone or in combination, there was a significant increase in germination, reaching $72 \%$ in Heat- 2 and $81 \%$ in Heat-2 Osm-1 (Table 1). This suggests that the treatment had some action on the E. brasiliensis seed metabolism.
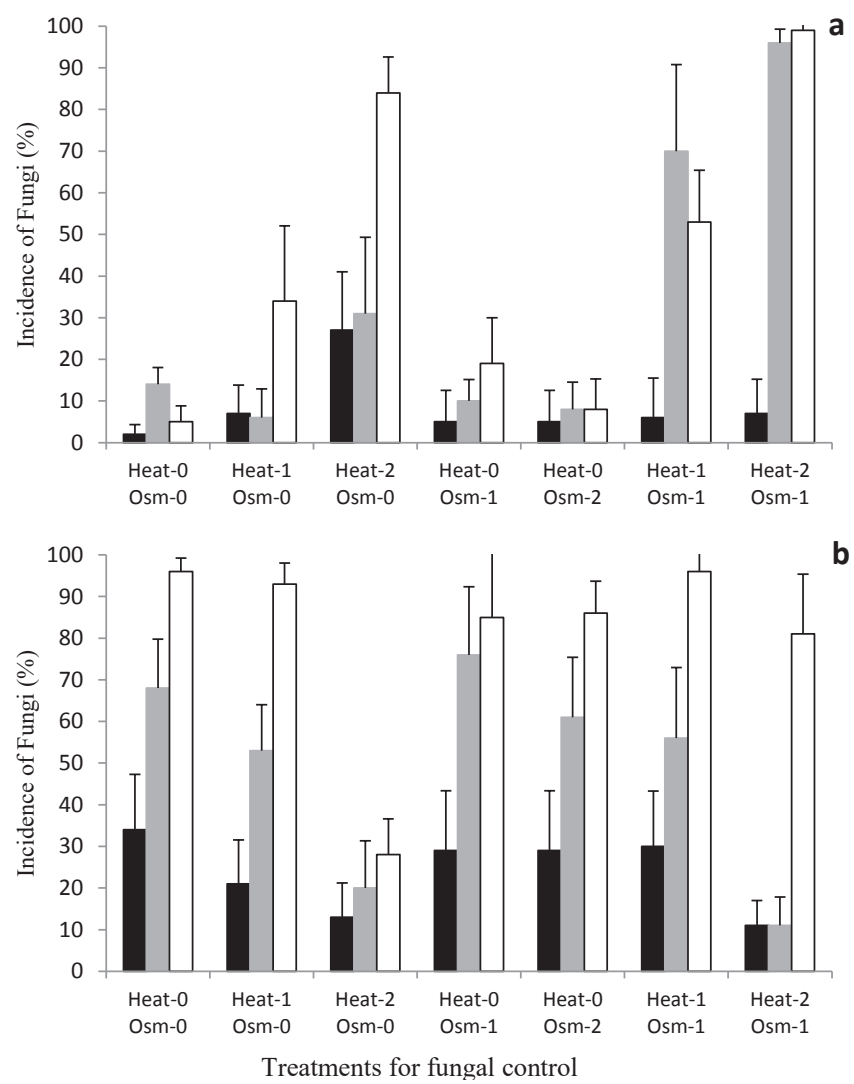

Figure 3. Incidence (\%) of Penicillium sp. (a) and Fusarium sp. (b) in seeds of E. brasiliensis subjected to heat treatments (Heat-0: no heat treatment; Heat-1: 55 ${ }^{\circ} \mathrm{C} / 30 \mathrm{~min}$; Heat-2: $55{ }^{\circ} \mathrm{C} / 150 \mathrm{~min}$ ) and osmotic treatments (Osm-0: no osmotic treatment; Osm1: $-3.4 \mathrm{MPa} / 7$ days; Osm-2: $-3.4 \mathrm{MPa} / 7$ days reapplied at 30 days). Black bars: non-stored seeds; gray bars: after 30 days of storage; white bars: after 60 days of storage. The means and standard deviations are shown.

After storage, it was found that, unlike the initial result, Heat-0 Osm-0 of E. brasiliensis showed $81 \%$ germination (Table 3); however such seeds showed an increase in the incidence (Figure $3 \mathrm{~B}$ ) and severity of Fusarium sp., with up to $20 \%$ of moderate to high development of the 
fungus (Figures $4 \mathrm{D}$ and F). In this way, it can be seen that the increase in the formation of normal seedlings is not positively related to the physiological quality and health quality of these seeds, which suggests a progression of seed deterioration during storage and an increase in the severity of the infection.
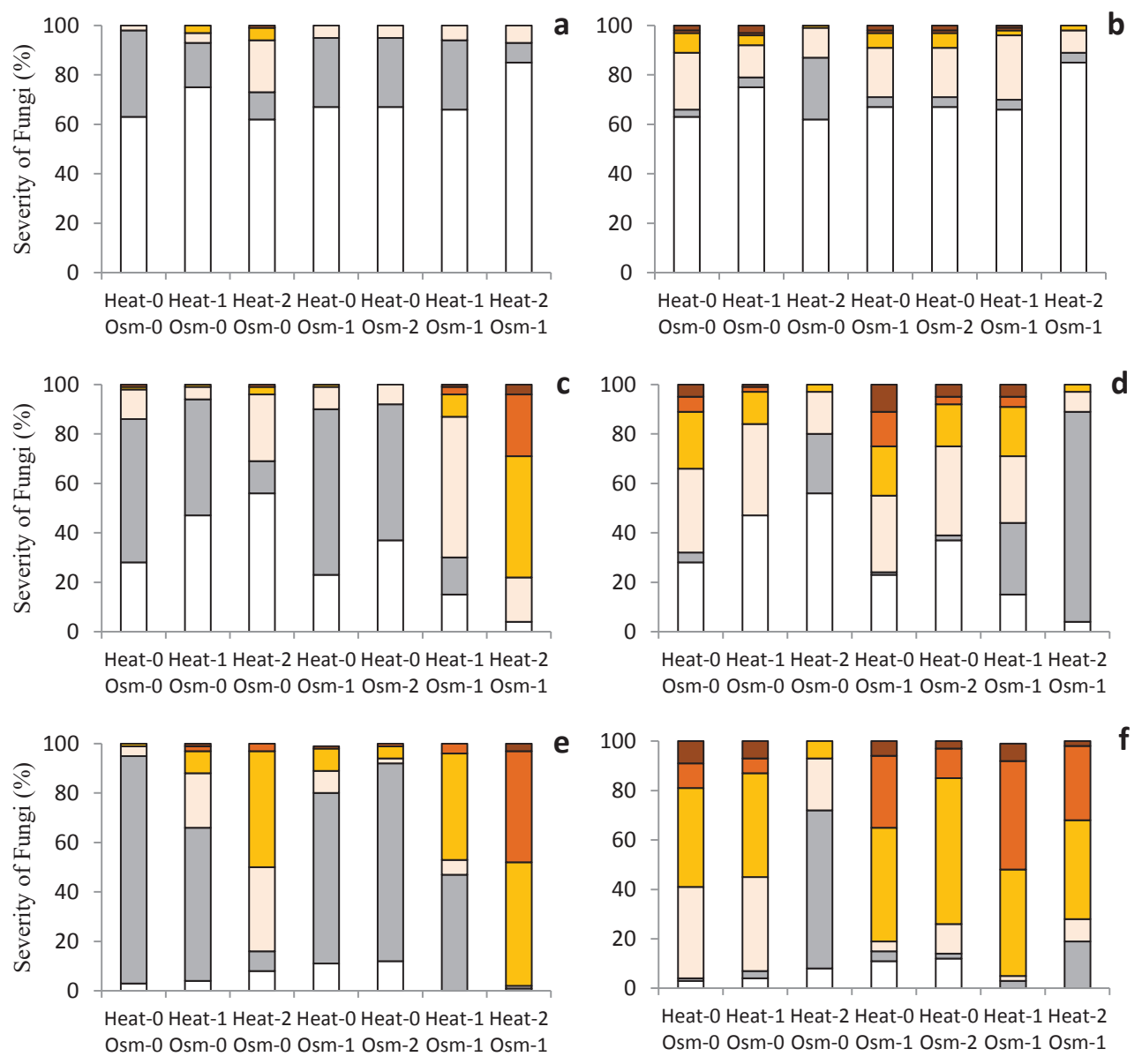

Treatments for fungal control

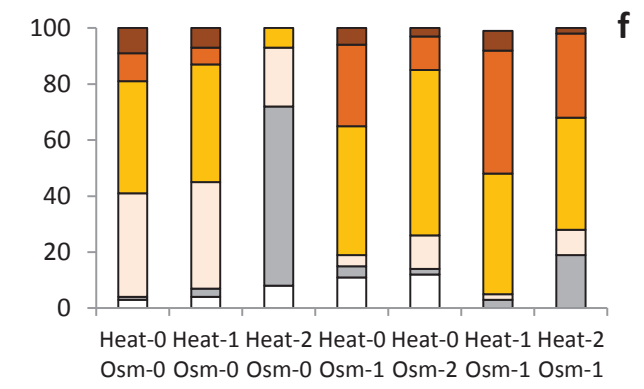

Treatments for fungal control

$\square$ Non-infected $\square$ Zero $\square$ Traces $\square$ Low aModerate $\square$ High

Figure 4. Severity (\%) initially (a and b) and after storage for 30 ( $\mathrm{c}$ and d) and 60 days (e and f) of Penicillium sp. (a, c and e) and Fusarium sp. (b,d and f) in seeds of E. brasiliensis subjected to heat treatments (Heat-0: no heat treatment; Heat-1: $55^{\circ} \mathrm{C} / 30 \mathrm{~min}$; Heat-2: $55^{\circ} \mathrm{C} / 150 \mathrm{~min}$ ) and osmotic treatments (Osm-0: no osmotic treatment; Osm-1: -3.4 $\mathrm{MPa} / 7$ days; Osm-2: -3.4 MPa/7 days reapplied at 30 days). Caption: Zero - seed not infected by the analyzed fungus; Traces - small colonies, and in a very small number; Low - weak and sparse growth up to $40 \%$ of the seed; Moderate moderate growth from 41 to $100 \%$ of the seed, with colonies with superficial and slow growth; High - intense growth from 41 to $100 \%$ of the seed, with dense and evenly distributed colony. Means are show in percentage terms.

In E. brasiliensis, the seeds subjected to heat treatments, alone or combined, showed a higher incidence of Penicillium sp. (Figure 3), mainly at 60 days of storage. However, the severity of their development tends to be reduced, especially in the heat treatment applied alone. The heat treatment itself, given its application in a wet medium, may facilitate the dissemination of fungus spores, and a reduction in the severity of Fusarium sp. may leave the niche free for the development of Penicillium sp., which develops in an opportunistic manner, without high severity.

The seeds of E. pyriformis and E. brasiliensis showed sensitivity to Osm-1 and Osm-2, with significant reduction of germinable seeds and germination. Along the storage period, such seeds continued to show lesser vigor (Tables 1 and 2), 
with increased severity of Fusarium sp., mainly at 60 days of storage (Figures $2 \mathrm{~F}$ and $4 \mathrm{~F}$ ). However, unlike E. pyriformis, in E. brasiliensis, the association of Osm-1 with the heat treatment did not reduce this negative effect and also led to a significant increase in the severity of Penicillium sp. (Figures 2 and 4).

Table 2. Germinable seeds (\%), germination (\%) and abnormal seeds (\%), initially and after 30 and 60 days of storage of Eugenia brasiliensis subjected to heat treatments (Heat-0: no heat treatment; Term-1: $55^{\circ} \mathrm{C} / 30 \mathrm{~min}$; Heat-2: $\left.55^{\circ} \mathrm{C} / 150 \mathrm{~min}\right)$ and osmotic treatments (Osm-0: no osmotic treatment; Osm-1: -3.4 MPa/7 days; Osm-2: -3.4 MPa/7 days reapplied at 30 days $)^{(1)}$.

\begin{tabular}{|c|c|c|c|}
\hline \multirow{3}{*}{ Seed treatments } & \multicolumn{3}{|c|}{ Storage } \\
\hline & Initial & 30 days & 60 days \\
\hline & \multicolumn{3}{|c|}{ Germinable Seeds } \\
\hline Heat-0 Osm-0 & $82 \mathrm{aA}$ & $91 \mathrm{aA}$ & $86 \mathrm{abA}$ \\
\hline Heat-1 Osm-0 & $84 \mathrm{aA}$ & $94 \mathrm{aA}$ & $87 \mathrm{abA}$ \\
\hline Heat-2 Osm-0 & $90 \mathrm{aA}$ & $95 \mathrm{aA}$ & 99 aA \\
\hline Heat-0 Osm-1 & $25 \mathrm{cB}$ & $68 \mathrm{bA}$ & $65 \mathrm{cA}$ \\
\hline Heat-0 Osm-2 & $25 \mathrm{cC}$ & $56 \mathrm{bB}$ & $75 \mathrm{bcA}$ \\
\hline Heat-1 Osm-1 & $59 \mathrm{bB}$ & $88 \mathrm{aA}$ & $80 \mathrm{bA}$ \\
\hline Heat-2 Osm-1 & $94 \mathrm{aA}$ & $93 \mathrm{aA}$ & $97 \mathrm{aA}$ \\
\hline \multirow{2}{*}{$\mathrm{CV}$} & $8.72 \%$ & & \\
\hline & \multicolumn{3}{|c|}{ Germination } \\
\hline Heat-0 Osm-0 & $31 \mathrm{bcB}$ & $81 \mathrm{aA}$ & 75 abcdA \\
\hline Heat-1 Osm-0 & $26 \mathrm{bcB}$ & $89 \mathrm{aA}$ & $81 \mathrm{abcA}$ \\
\hline Heat-2 Osm-0 & $72 \mathrm{aB}$ & $87 \mathrm{aA}$ & $92 \mathrm{aA}$ \\
\hline Heat-0 Osm-1 & $14 \mathrm{cB}$ & $52 \mathrm{bA}$ & $60 \mathrm{dA}$ \\
\hline Heat-0 Osm-2 & $14 \mathrm{cC}$ & $41 \mathrm{bB}$ & $68 \mathrm{cdA}$ \\
\hline Heat-1 Osm-1 & $38 \mathrm{bB}$ & $74 \mathrm{aA}$ & $73 \mathrm{~A}$ \\
\hline Heat-2 Osm-1 & $81 \mathrm{aA}$ & $77 \mathrm{aA}$ & $88 \mathrm{abA}$ \\
\hline \multirow[t]{2}{*}{$\mathrm{CV}$} & $13.73 \%$ & & \\
\hline & \multicolumn{3}{|c|}{ Abnormal } \\
\hline Heat-0 Osm-0 & $51 \mathrm{aA}$ & $10 \mathrm{aB}$ & $11 \mathrm{aB}$ \\
\hline Heat-1 Osm- 0 & $58 \mathrm{aA}$ & $4 \mathrm{aB}$ & $6 \mathrm{aB}$ \\
\hline Heat-2 Osm-0 & $18 \mathrm{bA}$ & $8 \mathrm{aA}$ & $7 \mathrm{aA}$ \\
\hline Heat-0 Osm-1 & $11 \mathrm{bA}$ & $10 \mathrm{aA}$ & $5 \mathrm{aA}$ \\
\hline Heat-0 Osm-2 & $11 \mathrm{bA}$ & $15 \mathrm{aA}$ & $7 \mathrm{aA}$ \\
\hline Heat-1 Osm-1 & $21 \mathrm{bA}$ & $14 \mathrm{aAB}$ & $7 \mathrm{Ab}$ \\
\hline Heat-2 Osm-1 & $13 \mathrm{bA}$ & $16 \mathrm{aA}$ & $9 \mathrm{aA}$ \\
\hline $\mathrm{CV}$ & $46.63 \%$ & & \\
\hline
\end{tabular}

${ }^{(1)}$ Means followed by the same letter (lower case: comparison within the columns; capital letters: comparison within the rows) do not differ by Tukey's test at $5 \%$ probability.
Although the osmotic treatment subjects seeds to water stress, there is no significant reduction in the water content of these seeds (Table 3); it remained above the value deemed critical to the species (Delgado and Barbedo, 2007). Thus, although the above-mentioned stress has influenced the development of the fungi, it caused no desiccation, acting differently in the metabolism of these seeds.

Therefore, the seeds may have been intolerant to water stress caused by the osmotic treatment, which was not observed by Françoso and Barbedo (2014) and Oliveira et al. (2011) for seeds of $E$. brasiliensis subjected to osmotic treatments of $-3.4 \mathrm{MPa} / 7$ days and $-4.0 \mathrm{MPa} / 7$ days (germination of $90 \%$ for both of them) and by Oliveira et al. (2011), who found germination above $80 \%$ for seeds of E. pyriformis submitted to treatment of $-2.5 \mathrm{MPa} / 7$ days. It is known that environmental conditions can affect the development period prior to seed dispersal, and seeds can be dispersed when somewhat developed. Consequently, they are less tolerant to stresses such as desiccation, as evidenced by Lamarca et al. (2013) in seeds of E. pyriformis.

In general, osmotic and heat treatments control the majority of fungi present in the analyzed seeds, but they also have effects on the metabolism of these seeds. Further studies are needed in order to clarify what changes can occur and how they act in order to better understand the behavior of these seeds and make their storage feasible.

Furthermore, differences between the two species of Eugenia in the effect of the same treatment for control of Fusarium sp. and Penicillium sp. suggest that the indirect effects of the application of treatments, i.e., on the seeds, play an important role in fungal control, and should be considered together with the direct effect, on the fungi themselves.

Moraes et al. (2003) found that severity is a more sensitive test compared with incidence, but they emphasize that this would not be an easy-to-apply evaluation method not only because it is subjective but also more time-consuming for evaluation purposes. The authors used a 0-10 scale, and considered increases of $10 \%$ in the area of the seed covered by the fungus from one level of the scale to another. We do believe that simplifying the previous scale, based on ten levels, to this one, based on five levels, allowed an easier and faster evaluation, however not reducing the quality of the results, which had satisfactorily shown the distribution and trends of development of the fungi in the different analyzed cases. 
Table 3. Water content (\%), initially and after 30 and 60 days of storage, of E. pyriformis and Eugenia brasiliensis subjected to heat treatments (Heat-0: no heat treatment; Heat-1: $55{ }^{\circ} \mathrm{C} / 30 \mathrm{~min}$; Heat-2: $55{ }^{\circ} \mathrm{C} / 150 \mathrm{~min}$ ) and osmotic treatments (Osm-0: no osmotic treatment; Osm-1: -3.4 MPa/7 days; Osm-2: -3.4 MPa/7 days reapplied at 30 days) $)^{(1)}$.

\begin{tabular}{|c|c|c|c|c|}
\hline \multirow{3}{*}{ Seed treatments } & \multicolumn{3}{|c|}{ Storage } & \multirow{3}{*}{ Means } \\
\hline & Initial & 30 days & 60 days & \\
\hline & \multicolumn{3}{|c|}{ E. pyriformis } & \\
\hline Heat-0 Osm-0 & $59.9 \mathrm{bB}$ & $66.4 \mathrm{aA}$ & $66.3 \mathrm{abA}$ & \\
\hline Heat-1 Osm-0 & $65.8 \mathrm{aA}$ & $66.2 \mathrm{aA}$ & $65.2 \mathrm{abA}$ & \\
\hline Heat-2 Osm-0 & $65.8 \mathrm{aA}$ & $65.5 \mathrm{aA}$ & $66.7 \mathrm{aA}$ & \\
\hline Heat-0 Osm-1 & $60.5 \mathrm{bB}$ & $65.2 \mathrm{aA}$ & $65.5 \mathrm{abA}$ & \\
\hline Heat-0 Osm-2 & $60.5 \mathrm{bA}$ & $60.2 \mathrm{bA}$ & $64.7 \mathrm{abB}$ & \\
\hline Heat-1 Osm-1 & $59.9 \mathrm{bB}$ & $63.9 \mathrm{abA}$ & $63.0 \mathrm{abAB}$ & \\
\hline Heat-2 Osm-1 & $58.9 \mathrm{Bb}$ & $62.5 \mathrm{abA}$ & $62.5 \mathrm{bA}$ & \\
\hline \multirow[t]{2}{*}{$\mathrm{CV}$} & $3.06 \%$ & & & \\
\hline & \multicolumn{3}{|c|}{ E. brasiliensis } & \\
\hline Heat-0 Osm-0 & 49.8 & 52.1 & 49.8 & $50.6 \mathrm{ab}$ \\
\hline Heat- 1 Osm-0 & 50.0 & 52.1 & 51.2 & $51.1 \mathrm{a}$ \\
\hline Heat-2 Osm-0 & 49.9 & 53.8 & 50.7 & $51.5 \mathrm{a}$ \\
\hline Heat-0 Osm-1 & 48.6 & 48.2 & 46.9 & $47.9 \mathrm{c}$ \\
\hline Heat-0 Osm-2 & 48.6 & 48.1 & 46.6 & $47.8 \mathrm{c}$ \\
\hline Heat-1 Osm-1 & 48.8 & 48.8 & 48.3 & $48.7 \mathrm{c}$ \\
\hline Heat-2 Osm-1 & 48.2 & 49.2 & 48.9 & $48.8 \mathrm{bc}$ \\
\hline Means & $49.1 \mathrm{~B}$ & $50.3 \mathrm{~A}$ & $48.9 \mathrm{~B}$ & \\
\hline $\mathrm{CV}$ & $3.02 \%$ & & & \\
\hline
\end{tabular}

${ }^{(1)}$ Means followed by the same letter (lower case: comparison within the columns; capital letters: comparison within the rows) do not differ by Tukey's test at $5 \%$ probability.

\section{Conclusions}

The use of severity in the health assessment of the seeds of E. pyriformis and E. brasiliensis can detect differences between treatments not identified by incidence evaluation, as shown in the osmotic and heat treatments which controled most of the fungi present in these seeds, but not the incidence of Fusarium sp. and Penicillium sp.

\section{Acknowledgments}

The authors would like to thank the National Council for Scientific and Technological Development (CNPq) for their financial support to the project and the research scholarship granted to the second author; the São Paulo State Research Foundation (FAPESP), for the doctoral scholarship granted to the first author; the Post-graduation in Plant Biodiversity and Environment, Institute of Botany, for the opportunity of completing the doctoral course; the Institute of Botany, for permission to collect the fruits.

\section{References}

ANDRÉO, Y.; NAKAGAWA, J.; BARBEDO, C.J. Mobilização de água e conservação da viabilidade de embriões de sementes recalcitrantes de ingá (Inga vera Will. subsp. affinis (DC.) T.D. Pennington). Revista Brasileira de Botânica, v.29, n.2, p.309-318, 2006. http://www.scielo.br/pdf/rbb/v29n2/ a12v29n2.pdf

BARNETT, H.L.; HUNTER, B.B. Ilustrated genera of imperfect fungi. 3ed. Minnesota, Burgess Publishing Company, 1999. 241p.

BRASIL. Ministério da Agricultura, Pecuária e Abastecimento. Regras para análise de sementes. Ministério da Agricultura, Pecuária e Abastecimento. Secretaria de Defesa Agropecuária. Brasília: MAPA/ACS, 2009. 395p. http:// www.agricultura.gov.br/arq editor/file/2946 regras analise sementes.pdf

DECAGON. WP4 Dewpoint PotentaMeter Operator's Manual. Pullman: Decagon Devices, Inc. 2001. 78p.

DELGADO, L.F.; BARBEDO, C.J. Tolerância à dessecação de sementes de espécies de Eugenia. Pesquisa Agropecuária Brasileira, v.42, n.2, p.265-272, 2007. http://www.scielo.br/pdf/pab/v42n2/16.pdf

DELGADO, L.F.; BARBEDO, C.J. Water potential and viability of seeds of Eugenia (Myrtaceae), a tropical tree species, based upon different levels of drying. Brazilian Archives of Biology and Technology, v.55, n.4, p.583-590, 2012. http://www.scielo.br/pdf/babt/v55n4/a14v55n4.pdf 
FRANÇOSO, C.F.; BARBEDO, C.J. Tratamentos osmóticos e térmicos para controle de fungos em sementes de grumixameira (Eugenia brasiliensis Lam.) e pitangueira (Eugenia uniflora L.). Hoehnea, v.41, n.4, p.541-552, 2014. http://www.scielo.br/hoehnea/v41n4/hoehnea.pdf

ISTA. International rules for seed testing. The International Seed Testing Association, Bassersdorf, Switzerland. 2016. 284p. http://dx.doi. org/10.15258/istarules.2016.F

KOHAMA, S.; MALUF, A.M.; BILIA, D.A.C.; BARBEDO, C.J. Secagem e armazenamento de sementes de Eugenia brasiliensis Lam. (grumixameira). Revista Brasileira de Sementes, v.28, n.1, p.72-78, 2006. http://www.scielo. br/pdf/rbs/v28n1/a10v28n1.pdf

LAMARCA, E.V.; PRATAVIERA, J.S.; BORGES, I.F.; DELGADO, L.F.; TEIXEIRA, C.C.; CAMARGO, M.B.P.; FARIA, J.M.R.; BARBEDO, C.J. Maturation of Eugenia pyriformis seeds under different hydric and thermal conditions. Anais da Academia Brasileira de Ciências, v.85, n.1, p.223-233, 2013. http://www.scielo.br/pdf/aabc/v85n1/0001-3765-aabc-85-01-223.pdf

MACHADO, A.Q.; MACHADO, J.C.; VIEIRA, M.D.G.G.C.; CASSETARI NETO, D.; SOUZA, M.V. Potencial do uso da restrição hídrica em testes de sanidade de sementes de algodoeiro. Fitopatologia Brasileira, v.32, n.5, p.408-414, 2007. http://www.scielo.br/pdf/fb/v32n5/v32n5a06.pdf

MICHEL, B.E.; KAUFMANN, M.R. The osmotic potential of polyethylene glicol 6000. Plant Physiology, v.51, n.5, p.914-916, 1973. http://www. plantphysiol.org/content/51/5/914.full.pdf + html
MORAES, M.H.D.; MENTEN, J.O.M.; GRAVENA, J.C.; ALVES, C.A. Controle químico de Fusarium moniliforme em sementes de milho: metodologia de avaliação e efeitos sobre a qualidade fisiológica. Fitopatologia Brasileira, v.28, n.6, p.626-632, 2003. http://www.scielo.br/ $\mathrm{pdf} / \mathrm{fb} / \mathrm{v} 28 \mathrm{n} 6 / \mathrm{a} 08 \mathrm{v} 28 \mathrm{n} 6 . \mathrm{pdf}$

OLIVEIRA, C.F.; OLIVEIRA, D.C.; PARISI, J.J.D.; BARBEDO, C.J. Deterioração de sementes de espécies brasileiras de Eugenia em função da incidência e do controle de fungos. Revista Brasileira de Sementes, v.33, n.3, p.520-532, 2011. http://www.scielo.br/pdf/rbs/v33n3/15.pdf

PARISI, J.J.D.; BIAGI, J.D.; BARBEDO, C.J.; MEDINA, P.F. Viability of Inga vera Willd. subsp. affinis (DC.) T.D. Penn. embryos according to the maturation stage, fungal incidence, chemical treatment and storage. Journal of Seed Science, v.35, n.1, p.70-76, 2013. http://www.scielo.br/pdf/jss/ v35n1/10.pdf

PARISI, J.J.D.; BIAGI, J.D.; MEDINA, P.F.; BARBEDO, C.J. Fungicide and drying effects on the viability of recalcitrant seeds of Inga vera subsp. affinis. Tropical Plant Pathology, v.41, p.177-182, 2016. http://link.springer.com/ article/10.1007\%2Fs40858-016-0084-6

SANTANA, D.G.; RANAL, M. Análise da germinação: um enfoque estatístico. Ed. Universidade de Brasília, Brasília, 2004. 248p.

TANAKA, M.A.S.; ITO, M.F.; BRAGA, C.A.S.; ARMOND, G. Tratamento térmico solar da água para controle de fitopatógenos. Fitopatologia Brasileira, v.28, n.4, p.386-393, 2003. http://www.scielo.br/pdf/fb/v28n4/17012.pdf 